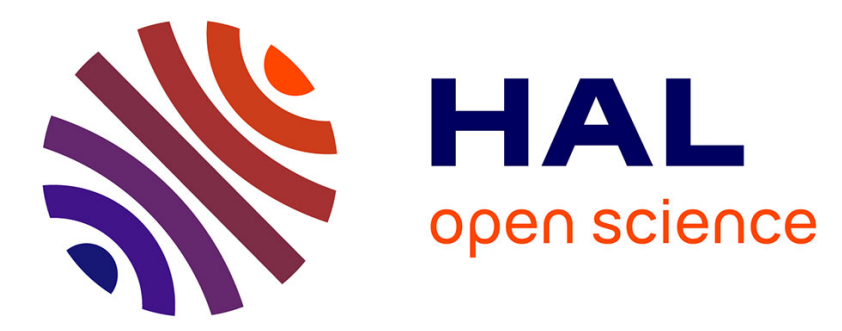

\title{
XAFS Study of CuI-Y and CuII-Y Interacting with CO and NO
}

F. d'Acapito, G. Turnes Palomino, C. Lamberti, S. Bordiga, C. Pazé, G. Spoto, A. Zecchina

\section{- To cite this version:}

F. d'Acapito, G. Turnes Palomino, C. Lamberti, S. Bordiga, C. Pazé, et al.. XAFS Study of CuIY and CuII-Y Interacting with CO and NO. Journal de Physique IV Proceedings, 1997, 7 (C2), pp.C2-903-C2-904. 10.1051/jp4:1997273 . jpa-00255356

\section{HAL Id: jpa-00255356 https://hal.science/jpa-00255356}

Submitted on 1 Jan 1997

HAL is a multi-disciplinary open access archive for the deposit and dissemination of scientific research documents, whether they are published or not. The documents may come from teaching and research institutions in France or abroad, or from public or private research centers.
L'archive ouverte pluridisciplinaire HAL, est destinée au dépôt et à la diffusion de documents scientifiques de niveau recherche, publiés ou non, émanant des établissements d'enseignement et de recherche français ou étrangers, des laboratoires publics ou privés. 


\title{
XAFS Study of $\mathrm{Cu}^{\mathrm{I}}-\mathrm{Y}$ and $\mathrm{Cu}^{\mathrm{II}}-\mathrm{Y}$ Interacting with $\mathrm{CO}$ and NO
}

\author{
F. D’Acapito, G. Turnes Palomino*, C. Lamberti**, S. Bordiga**, C. Pazé**, G. Spoto** and \\ A. Zecchina**
}

C.N.R. Roma Italy, c/o ESRF-GILDA CRG, Grenoble, France

* Departamento de Química, Universidad de las Islas Baleares, 07071 Palma de Mallorca, Spain

** Dipartimento di Chimica I.F.M., Via P. Giuria 7, 10125 Torino, Italy

\begin{abstract}
We report a study of the local copper environment in $\mathrm{Cu}-\mathrm{Y}$ prepared by gas phase reaction of $\mathrm{H}-\mathrm{Y}$ with $\mathrm{CuCl}$ and in $\mathrm{Cu}^{\mathrm{II}}-\mathrm{Y}$ prepared by conventional ion exchange with aqueous cupric salt. For the $\mathrm{Cu}-\mathrm{Y}$ sample, the effect of the interaction with $\mathrm{CO}$ and NO will also been reported. XANES, UV-Vis and IR (NO dosed at $77 \mathrm{~K}$ ) techniques prove that the copper species in the prepared samples have the desired oxidation state. Reduction of $\mathrm{Cu}^{\mathrm{I}}-\mathrm{Y}$ with $\mathrm{CO}$ leads to the formation of small copper clusters well identified by EXAFS, XANES and UV-Vis spectroscopies, while interaction with NO partially oxydate $\mathrm{Cu}^{\mathrm{l}}$ to $\mathrm{Cu}^{\mathrm{Il}}$. For both as prepared $\mathrm{Cu}-\mathrm{Y}$ and $\mathrm{Cu}-\mathrm{Il}$ samples EXAFS does not observe first shell $\mathrm{Cu}-\mathrm{Cu}$ bond lengths, so exciuding the presence of "so called" Cu-dimers in zeolites prepared following our methods.
\end{abstract}

\section{RESULTS AND DISCUSSION}

Copper exchanged zeolites (ZSM-5 and Mordenite) have recently reached a great interest in the direct conversion of NO into $\mathrm{N}_{2}$ and $\mathrm{O}_{2}[1,2]$, so stimulating the investigation of other copper exchanged zeolites. While $\mathrm{Cu}{ }^{\mathrm{II}}-\mathrm{Y}$ was prepared by conventional ion exchange with aqueous cupric salt, $\mathrm{Cu}^{\mathrm{I}}-\mathrm{Y}$ was prepared by an original gas phase reaction of $\mathrm{H}-\mathrm{Y}$ with $\mathrm{CuCl}$ already detailed elsewhere $[3,4]$. XAFS measurements, were performed at $300 \mathrm{~K}$ in transmission mode at GILDA D8 GRG bearnline [5] of ESRF in Grenoble F, (proposal CH132), equipped with a double crystal Si(331) monchromator detuned at $1 / 3$ of the rocking curve to avoid harmonics and operating in a dynamical sagittal focusing mode [6]. Incident and transmitted beams were recorded with a 1.0 Atm $\mathrm{N}_{2}$ filled $(10 \%$ efficiency) and with a $0.3 \mathrm{Atm}$ Ar filled ( $80 \%$ efficiency) ionization chamber respectively. A sampling step of $0.2 \mathrm{eV}$ for the XANES part of the spectra and a variable sampling step, giving rise to $\Delta \mathrm{k}_{\max }=0.05 \AA^{-1}$ for the EXAFS part and an integration time of $3 \mathrm{~s} /$ point have been adopted. The energy resolution in the experimental condition was estimated to be $0.5 \mathrm{eV}$ at $\mathrm{Cu}-\mathrm{K}$ edge. A $\mathrm{Cu}$ metal foil has been used for the angle/energy calibration. XAFS experiments have been performed using an ad hoc cell already described elsewhere [8], allowing in situ sample activation up to $800 \mathrm{~K}$ and gas dosage to be made. For each sample the EXAFS spectnum was acquired three times under the same experimental conditions and extracted $\chi(\mathrm{k})$ (using four cubic splines to compute the atomic adsorption) have been averaged before the EXAFS data analysis, which has been performed following standard procedures [8] using Michalovicz programs [9]. The $\mathrm{Cu}^{\mathrm{L}}-\mathrm{Y}$ sample has been measured at $\mathrm{RT}$ in the following conditions: i) vacuum; ii) after interaction with $\mathrm{CO}$; iii) after interaction with $\mathrm{NO}$; iv) after reduction at $500 \mathrm{~K}$ in $\mathrm{CO}$ atmosphere for one hour and subsequent evacuation (hereafter indicated as samples $Y, Y C O, Y N O$ and Yrid respectively). The $\mathrm{Cu}{ }^{\mathrm{II}}-\mathrm{Y}$ sample has been measured at RT only in vacuum conditions (hereafter indicated as sample $Y 2$ ). For this samples the activation treatment has been performed only at $400 \mathrm{~K}$ to avoid the thermal autoreduction of $\mathrm{Cu}^{\mathrm{II}}$ species. Fig. 1 reports the normalized XANES spectra of all samples, together with those of Copper metal, $\mathrm{Cu}_{2} \mathrm{O}$ and $\mathrm{CuO}$ model compounds. Y, YNO and Yrid samples show a XANES profile very similar to that of $\mathrm{Cu}_{2} \mathrm{O}$, denoting that the main copper species present in these sample exhibit the oxidation state I. However, the pre-edge lineshape of Yrid is characterized by an adsorption at lower energy, typical of copper in the metallic state. Spectrum of sample $Y C O$, shows and edge at the same energy of $\mathrm{Cu}_{2} \mathrm{O}$, but the intensity of its $1 s \rightarrow 4 p$ dipole-allowed transition at $8983 \mathrm{eV}$ is strongly damped. $Y 2$ sample has a XANES spectrum typical of $\mathrm{Cu}^{\text {II }}$ species; even if scarcely visible in Fig.1, both $\mathrm{Y} 2$ and $\mathrm{CuO}$ samples exhibit the same weak adsorption at $8977 \mathrm{eV}$ due to the dipoleforbidden $1 s \rightarrow 3 d$ transition. $\mathrm{k}^{3}$-weighted Fourier transform (FT), calculated in the range 3-13 $\AA^{-1}$ using a Kaiser window with $\tau=2.5$ of all zeolitic samples are reported in Fig. 2; for comparison the FT of $\mathrm{Cu}_{2} \mathrm{O}$ and copper metal (measured at 77 $\mathrm{K}$ and $\mathrm{k}^{3}$ transformed in the range 3-20 $\AA^{-1}$ ) are also present. No phase correction has been performed in the spectra reported in Fig. 2. Concerning samples measured in vacuum, both $Y 2$ and $Y$ exhibit a first coordination shell typical of Cu-O distances and no signal of $\mathrm{Cu}-\mathrm{Cu}$ are observed. The higher intensity of the first shell $\mathrm{Cu}-\mathrm{O}$ peak in $Y 2$, with respect to $Y$, is related to the higher first shell coordination number of $\mathrm{Cu}^{\mathrm{II}}$. The $\mathrm{d}(\mu \mathrm{x}) / \mathrm{dE}$ spectra of samples $Y 2, Y$ match very close with those of $\mathrm{CuO}$ and $\mathrm{Cu}_{2} \mathrm{O}$ model compounds (see Fig. 3). XAFS results thus prove that we were able to prepare isolated $\mathrm{Cu}$ sites in $\mathrm{Y}$ zeolite, having the desired oxidation state. Yrid sample, shows both $\mathrm{Cu}-\mathrm{O}$ and $\mathrm{Cu}-\mathrm{Cu}$ first shell coordination distances. This means that it contains both $\mathrm{Cu}^{\mathrm{I}}$ isolated species and small metal clusters trapped in the faujasitic supercage (11 $\AA$ in diameter). The presence of an higher shells signal typical of second, third and fourth coordination shells of FCC structures clearly show that we are dealing with metal cluster having a size comparable to those of the supercage. Powder XRD measurement on Yrid sample does not reveal the presence of Cu metal, implying that the size of the cluster must be smaller than $40 \AA$ in diameter. The hypothesis that $\mathrm{CO}$ reduction give rise to $\mathrm{Cu}$ cluster trapped in the zeolite cages is thus very plausible. Yrid sample still contains an high number of isolated $\mathrm{Cu}^{\mathrm{I}}$ species since its $\mu \mathrm{x}$ and $\mathrm{d}(\mu \mathrm{x}) / \mathrm{dE}$ spectra are still more close to that of $\mathrm{Cu}_{2} \mathrm{O}$. The strong $\mathrm{Cu}-\mathrm{Cu}$ signal in the FT is mostly due to the higher backscattering power of $\mathrm{Cu}$ (compared to $\mathrm{O}$ ). Quantitative results of our EXAFS analysis will be reported at the conference and discussed with the literature data [11,12]. Our results will be 
strongly supported by UV-Vis and IR study of dosed CO and NO molecules. We thank the ESRF Chem. Lab.

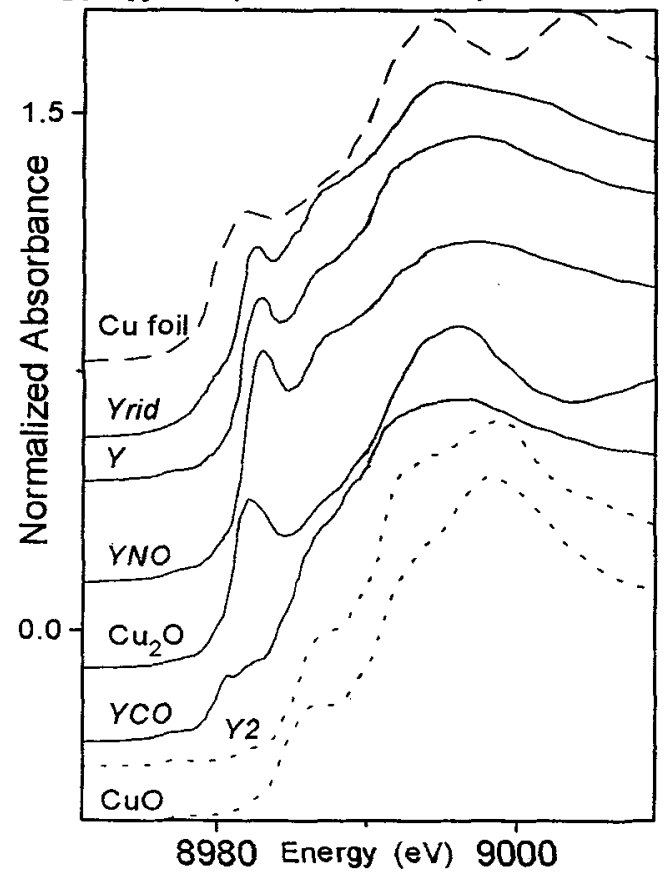

Figure 1: XANES spectra: dashed, full and doted curves indicates samples where $\mathrm{Cu}$ species have mainly $\mathrm{O}$, I and II as oxidation state.

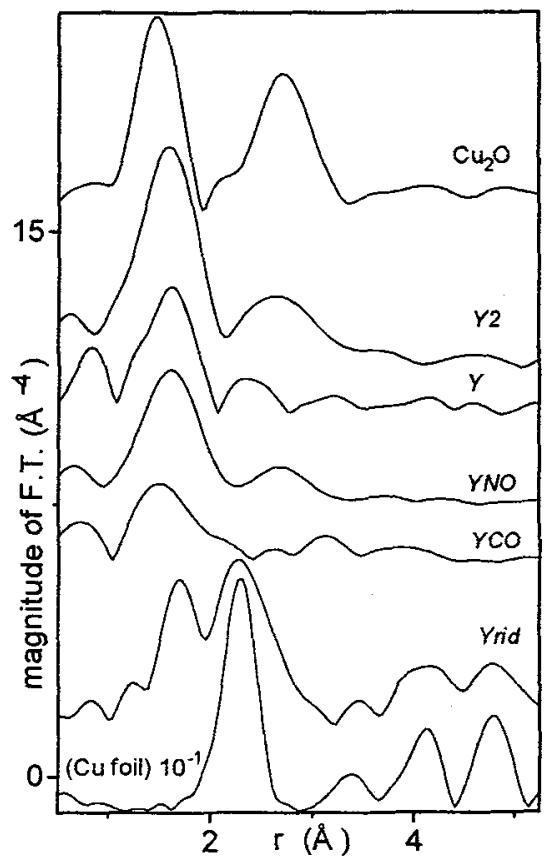

Figure 2: $\mathrm{k}^{3}$ weighted FT performed in the $3-20 \AA^{-1}(\mathrm{Cu}$ metal foil ) and 3-13 $\AA^{-1}$ (other samples) range.
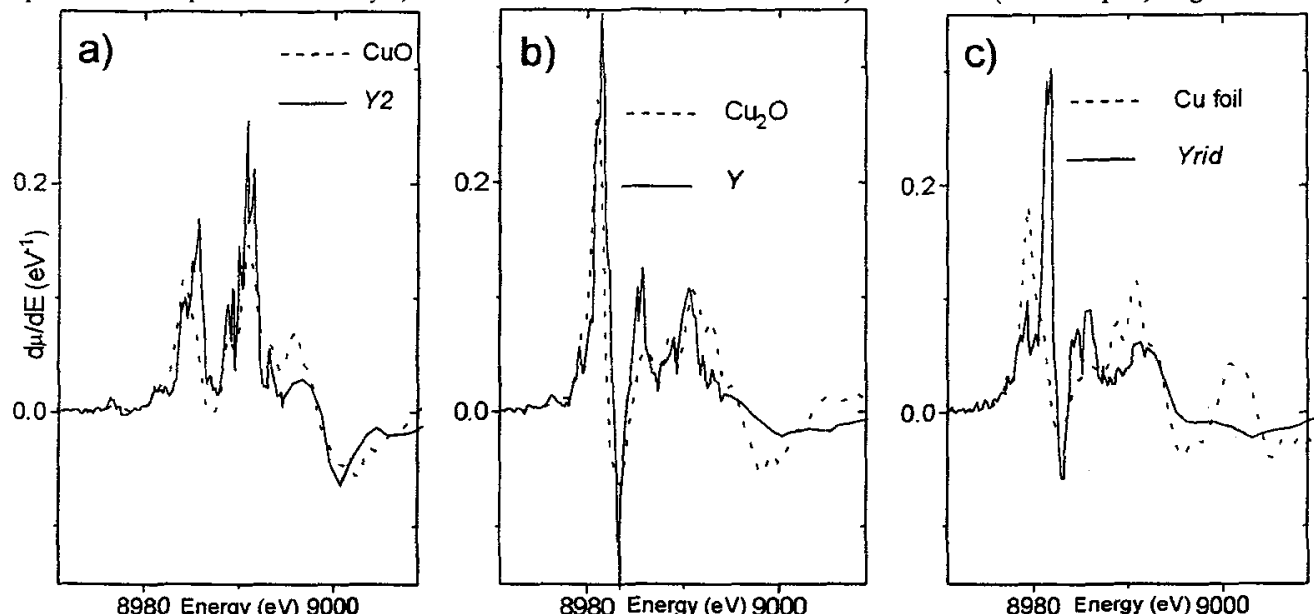

Figure 3: d( $(\mu \mathrm{x}) / \mathrm{dE}$ spectra of $Y 2, Y$ and $Y$ rid samples (parts a, b and c respectively) compared with spectra of model compounds.

\section{References}

[1] Iawamoto M. and Hamada H., Catal. Today 10 (1991) 57-71; Iawamoto M. et al., Appl.Catal. 69 (1991) L15-L19.

[2] Li Y. and Hall W. K., J. Phys. Chem. 94 (1990) 6145-6148; Iwamoto M., Stud. Surf. Sci. Catal. 54 (1990) 121-129.

[3] Spoto G. et al., Catal. Lett. 13 (1992) 39-44; Appl. Catal. B 3 (1994) 151-172.

[4] Spoto G. et al., J.Chem.Soc.Faraday.Trans. 91 (1995) 3285-3990; Lamberti C. et al., J. Phys. Chem. submitted.

[6] Pascarelli S. et al., ESRF Newsletters 23 (1995) 17-19.

[7] Pascarelli S., Boscherini F., D'Acapito F., Hrdy J., Meneghini C. and Mobilio S., J. Sync. Rad. 3 (1996) 147-155.

[8] Bordiga S. et al., J. Phys. Chem. 98 (1994) 4125-4132; Nucl. Instr. Meth. B 97 (1995) 23-27; J. Catal. 158 (1996) 486-501.

[9] Lytle F. W., Sayersand D. E. and Stern E. A., Co-Chairmen, Physica B 158 (1989) 701-722.

[10] Michalovicz, A. Ph.D. thesis, Université Paris Val de Marne 1990.

[11] Tanabe S. and Matsumoto H., J. Chem. Soc. Chem. Commun. (1989) 875-876; Bull. Chem. Soc. Jpn., 63 (1990), $192-198$.

[12] Matsumoto H. and Tanabe S., J. Phys. Chem., 94 (1990) 4207-4212; Yamashita H. et al., ibid., 100 (1996) 397-402. 